\title{
A Perspective on Productivity Growth and Challenges for the UK Economy
}

\section{Kalim SIDDIQUI ${ }^{10}$}

\section{ABSTRACT}

The UK's low levels of output per hour of labour and their productivity relative to other advanced economies is a matter for concern. The UK's productivity is a little over three-quarters that of Germany, the US, and France, and the about same as Italy. Furthermore, according to the OECD, it has been stagnant since 2007. Productivity is an important macroeconomic indicator as it demonstrates the output that an economy can generate using existing resources. It is generally acknowledged that technological progress, new research and technology can lead to higher investment and growth rates. Productivity refers to the quantity of goods and services that can be produced by a worker in a given period of time. For any economy, it is important to ensure rapid growth and a long-term trend of increased productivity. Indeed, this is particularly important for advanced economies where it is crucial to increase productivity in order to remain globally competitive. The study concludes that the UK's growth in productivity has been very slow relative to other major economies, and as a result the UK, which was already behind many other G7 countries, has fallen even further behind. This study suggests that a stronger and more viable manufacturing sector would help to build structural balance in the economy and to move it away from an over-reliance on the financial sector. To achieve this would require active state polices to increase investment in R\&D, innovation and skills.

Keywords: Labour productivity, growth, UK economy, Verdoorn's law, public investment

Jel Code: E11, O47, O51, N63, N64

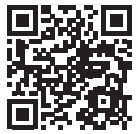

DOI: 10.26650/JEPR650998

'Dr., University of Huddersfield, Department of Accounting, Finance and Economics, Huddersfield, UK

ORCID: K.S. 0000-0002-7952-4573

\section{Corresponding author/Sorumlu yazar: Kalim SIDDIQUI, \\ University of Huddersfield, Department of Accounting, Finance and Economics, Huddersfield, UK \\ E-mail/E-posta: k.u.siddiqui@hud.ac.uk}

Submitted/Başvuru: 18.09.2019

Revision Requested/Revizyon Talebi:

12.11.2019

Last Revision Received/Son Revizyon:

25.11.2019

Accepted/Kabul: 27.11.2019

Citation/Atıf: Siddiqui, K. (2020). A Perspective on productivity growth and challenges for the UK economy. Iktisat Politikası Araştırmaları Dergisi - Journal of Economic Policy Researches, 7(1), 21-42.

https://doi.org/10.26650/JEPR650998 


\section{Introduction}

Productivity is an important macroeconomic indicator as it demonstrates the output that an economy can generate using existing resources. It is generally accepted that technological progress, new research and technology can lead to higher investment and growth rates. Labour productivity refers to the quantity of goods and services that can be produced by a worker in a given period of time.

The study intends to examine the factors behind the slow growth in productivity in the UK compared to the other G7 economies since the 1990s. This is important because growth in productivity has an impact on areas such as export competitiveness, balance of payments, and employment levels. The UK's low levels of output per hour of labour and its productivity relative to other advanced economies is, of course, a matter of some considerable concern. The UK's productivity is a little over three-quarters that of Germany, the US, and France, and is currently at about same level as that of Italy. Furthermore, according to the OECD, it has been stagnant since 2007.

This article analyses the UK manufacturing sector of the 1980s. The aim of this study is to stress the role of public spending in R\&D, thereby not only encouraging private investment in new technologies but also positively contributing to productivity and output. In recent years, the increased emphasis on austerity and cuts in public spending, especially since the 2008 crisis, seems to have adversely impacted growth in productivity. This study will be important for industry in terms of understanding such issues as employment, national income and international trade.

Manufacturing played a crucial role in the post-war economic boom, and contributed to securing employment opportunities and higher living standards. Since the 1980s in particular, manufacturing has witnessed a relative decline, both compared to earlier periods in the UK and also to other major economies such as Germany, Japan and the US. This is reflected in the UK's structural imbalance and is linked to its deep-rooted structural problems, with a rising national deficit, a reliance on finance which is largely unproductive and ongoing underinvestment in the UK's manufacturing sector. On this basis, one might anticipate that increased investment in manufacturing would lead to increased productivity. Of course, modern manufacturing in the 21 st century must make increased use of environmentally friendly technologies.

As Paul Krugman argues, "Productivity isn't everything, but in the long run it is almost everything". (Cited in Wolf, 2018) Improvements in standards of living depend almost entirely on rising output levels per worker. The productivity slowdown is one of the major reasons for the stagnation in workers' real incomes and the pressure to enact policies of 
fiscal austerity in advanced economies. The marked slowdown in the growth of incomes per head also explains the decline in labour's share of national income in advanced economies (Wolf, 2018).

For any economy, ensuring both rapid growth and long-term trends that show increased productivity are extremely important. Indeed, it is particularly important for advanced economies as it is crucial to increase productivity in order for them to remain globally competitive. In these economies, future income depends on raising output per hour. According to the OECD (2017), 73\% of the UK's population aged between 15 and 64 were in employment in 2015, as compared to $74 \%$ in Germany, $73 \%$ in Japan, $69 \%$ in the US, $64 \%$ in France and $57 \%$ in Italy. These high levels of employment should nominally imply that Britain is in a strong position. However, in terms of productivity, the UK's output per hour was only 16th in the world. According to 2015 statistics, the UK's output per hour was only $79 \%$ that of Germany, $78 \%$ that of the French, $77 \%$ that of the Netherlands, and $76 \%$ that of the US. However, even worse was the increase in output per hour between 2007 and 2015, at only $0.7 \%$, with the UK 17 th in the list of the high-income countries (Oulton, 2017).

The study explores the growth in productivity and the challenges faced by the UK's manufacturing sector since the 2008 crisis. Previous studies have not investigated these aspects extensively. This paper will evaluate the relationship between productivity and growth in output, known commonly as Verdoorn's law. The emphasis of this study is upon the growth in productivity depends on improvements in human skills. Capacity is defined as the ability to assemble resources and collectively generate output. Increased capacity means a greater potential flow of acts drawing upon that capacity. In fact, capacity is a stock, which can be expanded or reduced on the basis of a firm's acts and decisions with regards to policy. Increases in material productivity can also be a function of growth in the capacities of workers. If the capacity of such producers decreases, then productivity in terms of output will fall, even if all other factors remain constant. Workers have an interest in productivity increases insofar as they contribute to the satisfaction of their own needs for personal development.

This study has followed doctrinaire methodology, which includes analytical, descriptive and comparative methods. The methodology has been carefully chosen in order to enable us to answer the research questions posed herein. We have carefully identified appropriate categories and units of analysis, both of which reflect the nature of the data being analysed and the purpose of the research. In the process of performing comparative research, it should be understood that there exists a certain potential for theoretical development. This requires an awareness of both its strengths and limitations to ensure good practice. This also means having an understanding of different social contexts and the various issues which form parts of the actual processes of comparative research. 
The poor productivity of the UK economy seems to be associated with its structural crisis. In fact, unlike previous recessions, unemployment was not as extensive as in the past, but nonetheless real wages fell by an average of $1.7 \%$. The productivity shortfall between resource input and output growth in the UK has been very slow relative to other major economies, which is known as the 'productivity puzzle' (Pessoa et al., 2013). As a result, the UK, which was already lacking compared with many of the G7 countries, has fallen even further behind. Various factors have been proposed to be contributing to this lag. Some researchers believe that firms maintained their labour on relatively low wages rather than investing in human capital (investing in the workforce with the aim of raising skills and to boost morale and, ultimately, output and productivity), which resulted in stagnation in the output per worker (Green et al., 2016). Other critics stress that the risk aversion amongst the financial institutions has reduced access to bank loans for the purposes of investment, which has accordingly resulted in the inefficient allocation of resources across the economy (Oulton, 2017).

Certainly, there are differences in productivity from sector to sector. There has been relatively high productivity growth within the transport equipment sector, but a fall within the financial and insurance sectors. It has been well established that manufacturing contributes positively to overall economic growth. For the UK, the manufacturing sector is very important and there is a need to maintain a competitive advantage, not only for the sake of the export sector but indeed for the entire economy. Labour productivity is higher in manufacturing than in other sectors in the UK, and the productivity growth in this sector has been accompanied by a general fall in employment, which declined steadily between 1990 and 2015. However, productivity has fallen sharply since the 2008 recession. For the last two decades or so, production has become the centre of a very complex manufacturing value chain, characterised by different employment structures in low, medium and high technology industries. In the UK, manufacturing output peaked prior to the 2008 recession and since then has remained below 2007 levels. This sector has not only witnessed a decline in employment but also a marked shift in its employment profile, with a sharp increase in favour of highly qualified workers. Furthermore, current globalisation and increased international trade has opened new markets, especially in emerging economies.

\section{Theoretical Arguments}

For neoclassical economists technological progress and productivity depends upon an aggregate production function in which companies choose profit maximisation on the basis of price factors, and existing, capital-intensive techniques become more profitable to adopt as the economy moves along a stationary production function. There is an assumption of marginal productivity pricing and constant return to scale. Eventually, a shortfall between resource input and output growth can be interpreted as a shift in the production function as a 
result of technical progress (Mohun, 2009). Innovation achieves a temporary competitive advantage, but is undermined by successive technological advances resulting in labour saving and capital usage. As wages rise, this leads to the further application of labour-saving technology in order to maintain profits.

Sanjaya Lall (2001) emphasised the idea that technological skills and capabilities are important determinants of labour productivity increases. According to him, better technological skills and capabilities are highly pertinent to inducing economic growth by increasing the value added to outputs and exports. The achievement of this requires skilled workers. Skills, and human capital, are vital to achieving competitiveness in a globalised world. Previously, skills had often been treated as a generic factor and were generally measured by the number of years spent in education. However, this ignored the role of technology and associated skills in the creation of comparative advantages. According to the neoclassical economists' static model, in order to exploit their comparative advantages, countries should rely on their factor endowments and their effort to change via state promotion would be deemed inefficient. Lall (2001) distinguishes between two types of skills and capabilities, as acquired through formal education and/or formal or informal training. For the latter, he emphasised on-the-job-training. Finally, if more money is allocated to education and training, this creates the preconditions required for successful firm-level training and for facilitating the required capabilities to increase overall productivity.

Productivity can grow due to changes with existing firms, mainly through the introduction of new technology and through organisational change, which may also be referred to as internal change. The other factor contributing to productivity growth is that of new entrants to the market. These new entrants have higher productivities and an ability to expand their market share, leading to market exit for those who fail to maintain their competitive edge. The successful entrants are able to create competitive pressures within industry (Disney, Haskel \& Heden, 2003).

It is important to analyse the relationship between labour productivity and output growth, known as Verdoorn's law. Verdoorn proposed (1949) that increasing returns will occur due to the positive relationship between manufacturing output and labour productivity growth. His earlier empirical study was based on the UK's industrial output, from which he argued that industrial output was constrained by the growth of labour supply and, as a result, industrial productivity grew at a slower rate. Later, Kaldor (1975) presented an alternative to Verdoorn's law which could determine the growth rate of the economy as a whole, i.e., on a macro level. Verdoorn's effect, and Kaldor's model of technological progress, both emphasise the positive relationship between GDP and productivity growth. 
In the mid-1970s, the UK has been experiencing a slowdown in its GDP and productivity growths that only started to recover in the 1980s, but which have now once again declined to the rates seen in the early 1970s. This observation clearly indicates a positive relationship between GDP growth and productivity growth. Kaldor (1972) assumed endogenous technical change technical progress in his model; GDP growth and productivity growth are positively affected by the growth of capital intensity due to the assumption that technical progress is embodied by capital investment. In Verdoorn's law, the growth rate of labour productivity in industries is positively correlated with GDP growth rates, as explained by dynamic economies of scale, and the assertion that rationalisation and mechanisation will favourably affect overall productivity. Hein and Tarassow (2010:750) concluded: "Our estimations of the productivity regime for the six [OECD] countries in the period from 1960 to 2007 have confirmed the prevalence of a Verdoorn effect, i.e., a positive impact of GDP growth on productivity growth".

It is assumed by mainstream economists that recessions are the best time for cleansing and rooting out low productivity contributors to the economy. However, the empirical evidence for this is unclear; for example, in a recession many productive firms face closure due to a sharp downturn in demand in combination with credit constraints (Kitson \& Michie, 2014; Disney et al, 2003).

\section{Productivity Trends in the UK}

In the 1970 s, after slow growth in manufacturing productivity, the UK's industry witnessed an increase in the 1980s. Analysing the productivity changes in UK manufacturing since the 1980s indicates a sharp decline in the industrial contributions to GDP and exports in the 1970s, which has been referred to by some economists as deindustrialisation. Deindustrialisation has been widely defined in terms of both output and employment due to low productivity growth. If the relative decline in manufacturing has no adverse impact on employment or overall levels of economic activity, then it is not seen as problem. On the phenomenon of the deindustrialisation of the UK economy, the then Secretary for Industry, Tony Benn, observed in 1975: "The trend to contraction of British manufacturing industry which we are now suffering has gathered force in the last four years. If this trend is allowed to continue, we will have closed down $15 \%$ of our entire manufacturing capacity and nearly 2 million industrial workers will have been made redundant between 1970 and 1980. During the five years 1970-74 there was a 7\% fall in employment in manufacturing in Britain, while it was still rising in most of our competitor countries. In this period the total number of manufacturing jobs lost through redundancy averaged about 180,000 a year and the net contraction of manufacturing employment averaged 120,000 a year. Only about one in three of the jobs lost through redundancy were effectively replaced by the creation of a new job in the manufacturing sector" (cited in Singh, 1977: 13-14). 
On this issue, Ajit Singh's study (1997) concluded: "The deindustrialisation of the UK economy which has occurred in recent years has been only in the sense of loss of employment from the manufacturing sector. This loss has been greater than in other industrial countries, and also as compared with the trend rate of decline in the UK itself during the last two decades. Between the recession years of 1968 and 1976, employment in manufacturing fell by nearly 1 million workers; the proportion employed in manufacturing decreased from $36 \%$ to $32 \%$. There has, however, been no reduction in manufacturing output, although there was a slowdown in its rate of growth. It is in this important sense that, in spite of the growth in productivity, there is evidence that the UK manufacturing sector is becoming increasingly inefficient. The evidence suggests a structural disequilibrium, whereby the trading position of the manufacturing sector in the world economy continues to deteriorate, in spite of increasing cost and price competitiveness" (Singh, 1997:133-34).

During the Thatcher government in the 1980s, despite policy supporting the revival of the industrial sector, there was no increase in manufacturing. Such an increase did, in fact, occur in Germany and Japan during the same period (Siddiqui, 2015a). In the UK, high interest rates throttled manufacturing and facilitated a shift towards the service sector. During the same period, the UK government lifted the ban on anti-speculative restrictions and national saving funds, and insurance and mortgage providers benefitted from huge shifts in capital towards the financial services. At the same time, the privatisation of public housing and the major utilities, such as water, electricity, gas, railways, public transportation, and telecommunications attracted significant capital from private investors as they envisaged high returns with hardly any commitments to long-term infrastructure (van Ark, 1990).

Historically in the UK, particularly during the post-war boom, the manufacturing sector played an important role in the sense of driving productivity growth in the economy. To achieve this, the state made a leading contribution through investment in R\&D and human skills (Siddiqui, 1995). However, the neoliberal policy introduced to the UK in the 1980s led to a decrease in the role of the state and encouraged the greater role of market forces including deregulation, cuts in public expenditure, privatisation and a weakening of the role of trade unions (Siddiqui, 2015b). Some have argued that this policy shift led to improvements in competitive environments and as a result halted a relative decline (Craft, 2012). However, others have emphasised that the associated changes exacerbated the decline of manufacturing, which resulted in adverse long-term implications for both employment and trade. As Kitson and Michie (2014:17) note: "This decline of manufacturing was made worse during some parts of the period by demand shocks and constraints caused by shifts in macroeconomic policies. During the early 1980s, the focus on controlling inflation led to periodic overvaluation of exchange rate, which was particularly harmful during the monetarists in 1979-80 and during the UK's membership of the Exchange Rate Mechanism (ERM). When Britain was forced out of the ERM in September 1992 ..." 
With the further opening of the markets in the 1990s, manufacturing shrank to $17 \%$ of UK gross value added by 1997 , compared to $26 \%$ in Germany. This certainly contributed to the long-term decline of industries in Northern England and also to a chronic current account deficit, with the UK importing manufactured goods which were not made domestically. The New Labour government of 1997 continued previous policies and only slightly mitigated the effects through cosmetic measures such as taxing the credit system for 'hard-working families'. The Conservative government followed a policy of high interest rates and overvalued the pound, which hit the UK's manufacturing sector the worst. By contrast, the Labour government promised to lower unemployment and to help industries. However, with the increased globalisation of the 1990s and increased global capital mobility, the country's sectoral imbalances were exacerbated. The service sector ballooned to about $80 \%$ of output, compared to $69 \%$ in Germany, with profits disproportionately generated by the financial sector based in London and the South East regions. The Labour government did not adopt any clear initiative towards industrial policy (Kitson and Michie, 2014). Both Tony Blair and Gordon Brown's governments failed to make any real improvements in terms of reviving the manufacturing sector, and there were no real improvements in the living conditions of the average people in the UK. The economic growth that did occur, based heavily in the financial sector, was achieved by giving greater freedom to bankers and the super-rich (Hein and Tarassow, 2010).

The coalition government came to power in 2010, but was more preoccupied with the credit crunch, the global recession and public debts. Mainstream economists argue that the fact of 'too few producers', as a result of the rapid growth of the public sector during the post-war boom, was the main reason for deindustrialisation. According to them, this rapid expansion crowded resources which could otherwise have been used in the manufacturing sector. They presumed that the private sector was, relatively, more productive than the public sector (Bacon \& Eltis, 1976). However, whilst critics acknowledge that competition, availability of resources and market forces cannot be ignored, other factors demand that side conditions must be taken into account. Such views stress that these demands could impact the growth of manufacturing to a greater extent than a lack of resources (Kaldor, 1971). Kitson and Michie presented a more comprehensive explanation, according to which, "[F] our interlinked problems that have hampered UK manufacturing. First, underinvestment in manufacturing which resulted in British workers lacking the volume and quality of capital equipment compared to its main competitors. Second, much of this underinvestment was the result of short-termism in the financial sector which privileged short-term financial returns over long-term investment in capacity and technology. Third, there was a lack of a coherent industrial policy - in contrast to the strategy adopted in many other advanced industrial economies. Fourth, shifts in UK macroeconomic policy created an uncertain economic environment which has been particularly damaging for much of manufacturing, which is capital intensive and export-dependent”. (Kitson and Michie, 1996:21) 
In the UK, productivity fell sharply during the 2008 financial crisis. Some commentators have pointed out that it may have been structural, rather than simply cyclical, problems which led to the subsequent slowdown in productivity growth since the crisis. According to these commentators, it is far from just the global financial crisis causing the slump and it has been proposed that there are actually a number of causes, such as weak technical progress, falling aggregate demand and slow growth in factor productivity because of insufficient investment, particularly in education, training and infrastructure (Summers, 2014; Eichengreen, 2014). It seems that all these factors are, however, related to the 2008 financial crisis and are likely to be having a persistent impact on productivity.

Productivity estimates demonstrate an economy's ability to grow without generating any excessive inflationary pressure. It is also important to analyse the extent to which any slowdown in productivity is due to cyclical expiations related to demand conditions. This means during periods of recession, firms lower their resource utilisation due to a slowdown in the economy and weak demand. The other factor which seems to be contributing to the slowdown in productivity is the 2008 financial crisis seems to be a reduction in investment in both physical and intangible capital, e.g., innovation and slow transfer of resources from low to highly productive uses.

Labour productivity growth in the UK has been particularly weak since the 2008 financial crisis. Despite a modest increase in 2013, the whole economy output per hour remains at around $16 \%$ below pre-crisis productivity levels. In some sectors, this slow growth or near stagnation is referred to as the 'productivity puzzle'.

The UK's weak productivity needs to be compared with other advanced economies, particularly with regards to the events of the last decade. During this period, the UK's productivity performance appears to have grown weaker, i.e., the UK has underperformed compared to other advanced economies. In contrast to the UK, the US, despite a fall in GDP during the recession, saw its average output grow by 1.9\% between 2007 and 2012 and its labour productivity was $8 \%$ higher than the pre-2007 levels. The post-recession UK productivity performance seems to have been worse than in the majority of EU countries (Oulton and Sebastia-Barriel, 2013). One possible explanation for this is the lower levels of investment since the crisis of 2008. The estimates of TFP made by the Office for National Statistics indicate that the contribution of the growth of capital services per hour worked to increase the whole economy's GDP by \%1.2 in 2008, \%1.64 in 2009 and \%0.59 in 2010, i.e. positive for these three years (ONS, 2017). Though investment has fallen, the fall was not sufficiently large to result in a significant decline in per capita services per worker. Hence, the fall in investment cannot explain the fall in labour productivity. 
As Martin Wolf (2018) argues, "[W] eak investment and, above all, declining growth of "total factor productivity", a measure of output per input of capital and (quality-adjusted) labour. TFP is a measure of innovation, of the ability to produce more valuable output with given quantities of inputs. Without innovation, the rising prosperity of the past two centuries would have been impossible." In another study, Nicholas Crafts showed a decline in trend growth of TFP in the US from just above $1.5 \%$ a year in the early 1970 s to $0.9 \%$ most recently (cited in Wolf, 2018).

The UK is an important country for foreign investors, and the inward flow of foreign capital in Britain's assets and shares is larger than anywhere else in the world except the US and Hong Kong. In the last ten years, foreign investments totalled about $£ 600$ bn, equivalent to a third of the country's GDP. Figures indicate that inflows of capital are very important to British businesses and, indeed, the overall economy. In 2015, the UK's financial services accounted for nearly 95\% of net inflows. (Siddiqui, 2019) However, overall, the UK's productivity has not improved greatly. Official statistics suggest that foreign investors are doing less to improve the economy than had been initially presumed. Many factors are to blame, including poor infrastructure.

Since the 2016 Brexit vote, devaluation in sterling has helped manufacturing exports to some extent, as has quantitative easing and banks agreeing to provide increased credit to firms. However, all these efforts seem to have had limited success. Quantitative easing did not lead to any significant increase in investment in manufacturing. The performance of the manufacturing sector can be examined in terms of the conditions of supply and demand. Supply includes the cost of capital and technology, and also quality and cost of labour and innovation, in addition to competition. Demand includes domestic and overseas demands, exchange rates and tariffs and the degree of openness of markets. Kitson and Michie (2014:2) argue that supply conditions in manufacturing are, "[A]n uncompetitive environment which has led to low productivity growth and inadequate structural change ... such a focus ignores many of other constraints on manufacturing - in particular lack of investment leading to a low levels of capital (a supply constraint) and inadequate demand often due to an overvalued exchange rate (a demand constraint)".

Weak productivity growth may be due to firms retaining workers in the attempt to avoid the costs of recruiting skilled workers during the recovery phase or during the stagnation or decline in capital investment. This was due to a cautious approach to investing in new technologies, in addition to banks' general reluctance to lend money to businesses during a recession. The UK's manufacturing sector was slow to introduce economic reforms such as reward and profit-sharing incentives, minimal separation between management and workers, and there was relatively low investment in vocational education and skills improvements. 
Then the UK government policy was too late and relied more on ad hoc industrial policy with tax concessions, subsidies and short term polices rather than long-term initiatives.

Despite higher employment levels in 2017 in the UK, and indeed modest growth, the biggest risk to the country's future growth prospects is slow growth in "productivity". GDP per hour worked is lower at present than in 2007, i.e., prior to the financial crisis. Productivity improvements are an important source of GDP growth and increased living standards. US workers' output per hour is 9\% higher than in 2007 and in France it has increased by more than 2\%, but in the UK it has stalled. Compared to average G7 industrialised countries, the UK's productivity performance has been remarkably poor. Of course, this varies dramatically by sector. Ultimately, employing the same number of workers, while producing less, means that output per hour fell.

The UK has seen hardly any growth in terms of output per hour of work across the entire UK economy (see Table 1). Dismal performance in the UK's productivity is the biggest economic problem. Since 2016, productivity growth has seen a slight increase and by 2017, for which the latest figures are available, output per hour had risen by $1.7 \%$, which indicates the country's strongest performance since 2007 (Economist, 2018). The explanation seems to be the result of the lowest unemployment rates for several decades and a tighter labour market. Despite some slight gains in productivity, UK workers are some $15 \%$ less productive than other major economies, i.e., the G7.

Table 1: Output per hour worked in the UK

\begin{tabular}{cccccc}
\hline Year & Index 2013=100 & Annual change \% & & Index 2013=100 & Annual change \% \\
\hline 1996 & 80.5 & 1.5 & 2012 Q2 & 100.4 & -1.4 \\
1997 & 81.4 & 1.1 & 2012 Q3 & 100.5 & -0.9 \\
1998 & 83.5 & 2.6 & 2012 Q4 & 100.0 & -1.2 \\
1999 & 85.6 & 2.5 & 2013 Q1 & 100.2 & -0.7 \\
2000 & 88.7 & 3.6 & 2013 Q2 & 100.2 & -0.2 \\
2001 & 89.9 & 1.4 & 2013 Q3 & 99.6 & -1.0 \\
2002 & 92.0 & 2.3 & 2013 Q4 & 100.0 & 0.0 \\
2003 & 94.9 & 3.1 & $2014 \mathrm{Q} 1$ & 100.1 & -0.1 \\
2004 & 96.2 & 1.4 & 2014 Q2 & 100.3 & 0.0 \\
2005 & 98.0 & 1.9 & 2014 Q3 & 100.8 & 1.3 \\
2006 & 99.8 & 1.8 & 2014 Q4 & 101.2 & 1.3 \\
2007 & 101.4 & 1.6 & 2015 Q1 & 101.2 & 1.1 \\
2008 & 100.4 & -0.9 & 2015 Q2 & 101.8 & 1.5 \\
2009 & 98.8 & -1.6 & 2015 Q3 & 102.0 & 1.2 \\
2010 & 100.4 & 1.6 & 2015 Q4 & 101.0 & -0.3 \\
2011 & 101.3 & 0.9 & 2016 Q1 & 101.5 & 0.3 \\
2012 & 100.4 & -0.9 & 2016 Q2 & 101.8 & 0.0 \\
2013 & 100.0 & -0.4 & 2016 Q3 & 101.9 & -0.1 \\
2014 & 100.6 & 0.6 & 2016 Q4 & 102.4 & 1.4 \\
2015 & 101.5 & 0.9 & 2017 Q1 & 101.8 & 0.3 \\
2016 & 101.9 & 0.4 & 2017 Q2 & 101.8 & 0.0 \\
\hline
\end{tabular}

Source: http://researchbriefings.files.parliament.uk/documents/SN06492/SN06492.pdf 
The ONS (Office for National Statistics, 2017) data breaks down into 17 sectors. If we divide the share in GDP by the share in aggregate hours, then we obtain the relative labour productivity of each sector. This is the value added per hour in each sector divided by the aggregate value added (GDP) per hour. The level of productivity varies widely across sectors, from a low of 0.39 in agriculture and fishing to a high of 10.65 in oil and gas (ONS, 2017).

Figure 1: shows productivity changes in two sectors, i.e., services in manufacturing from 2007 to 2018
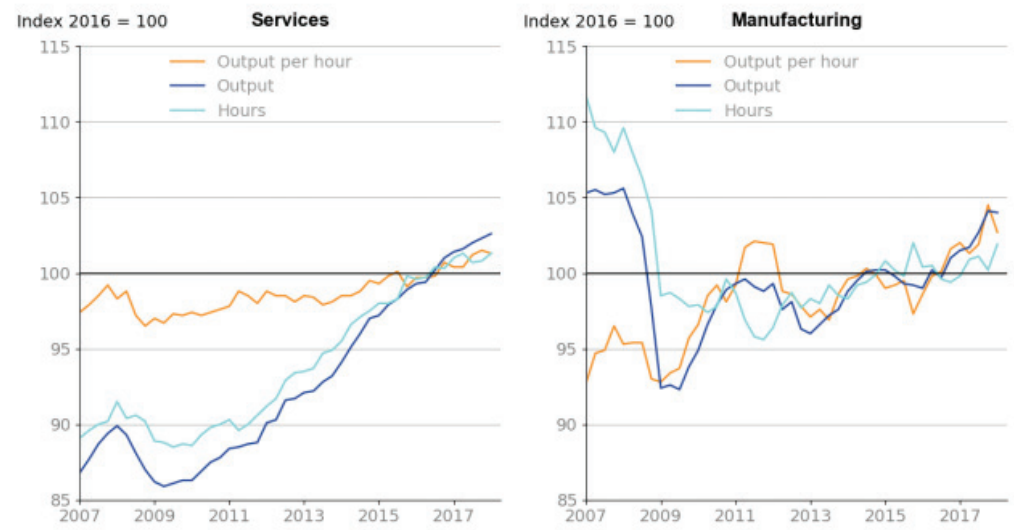

Notes: Components of Services and Manufacturing Productivity Measures in the UK, seasonally adjusted quarter 1 (January to March 2007 to quarter 1 2018). (Accessed on 10 November 2018)

Source: Office of National Statistics, July 2018. (Accessed on 5 March, 2019)

https://www.ons.gov.uk/employmentandlabourmarket/peopleinwork/labourproductivity/bulletins/labourproductivity/januarytomarch2018\# labour-productivity-up-for-the-sixth-consecutive-quarter-compared-with-a-year-ago

The car industry in the UK, which includes giants such as Jaguar, Land Rover, Mini, and Nissan, has witnessed an increase in productivity. For example, the car industry produced 11.5 vehicles per worker between 2011 and 2015, compared to 9.3 vehicles between 2005 and 2009. This was possible due to an increase in investment in new technologies, improved supply chain and better management, which all combine to make this sector more efficient.

In 2013, the labour productivity in manufacturing was 34\%, higher than in other sectors in the UK. The output per hour in pharmaceuticals saw lower productivity growth rates since 2007, but began to rise slowly after 2014.

The chemical and pharmaceuticals sector is hugely productive, but has stalled with hourly output dropping by $11 \%$ since 2008 . Real wages are down by $4 \%$ and employment levels have fallen by $5 \%$. The common cause in this sector seems to be their failure to invest 
in new technologies. In the pharmaceutical industry, the total expenditure was $£ 24.53$ bn in 2013 , which rose to $£ 24.67$ bn in 2014 , an increase of $0.59 \%$ (OECD, 2017). The UK's pharmaceutical market is one of the ten largest markets in the world.

In contrast to this, the worst-performing industries such as the financial and insurance sectors, currently have productivities which are $10 \%$ lower than in 2009 . The UK's textile industries had sharply declined from their World War I peak, with their export accounting for about $58 \%$ of the world textile trade (Siddiqui and Dahle, 1989). However, further sharp decline took place during World War II and as Japan, Germany and South Korea increased their exports; more recently, China and India have joined the global trade in textiles.

\section{The Role of Public Investment and Human Capital in Raising Productivity Levels}

In this section of the paper, the focus will be on gaining an understanding of the impact human development can have on productivity improvements. It is widely thought that the quality of human capital can have a significant impact on productivity. Therefore, an important question is how employers can be both persuaded and subsequently facilitated to increase their investment in training, skills and in overall human development.

The size of capital stock available to each unit of labour is an important determinant of labour productivity. After the financial crisis, increased economic uncertainty made firms more cautious about investment decisions, despite the fact that labour costs fell, while initially capital cost increased.

One possible explanation for this could be that persistent weakness in productivity growth could be due to reduced investments in physical and intangible capital. Pessoa and van Reenan (2013:3) noted: “[C]apital-labour ratios fell in response to changing factor prices, labour productivity has also fallen, but not necessarily the Total Factor Productivity (TFP). Since it is TFP that determines long-run economic growth, our view is that this is more important measure of productivity has been more resilient than usually imagined. Although there are many difficulties in accurately measuring the capital stock, our estimates suggest that most of the fall of labour productivity can be mainly accounted for by the fall in effective capital per worker (with some contribution from the fall in hour per worker). TFP trends over the recession look much more like in the 1970s and 1980s and are not so surprising given the magnitude of the global shock".

In the long run, productivity growth is important because it plays a crucial role in determining the material wellbeing of the associated populace. Labour productivity has fallen in the UK since the onset of the global crisis in 2008, and GDP per worker was nearly $10 \%$ lower at the beginning of 2014 than it would have been had productivity continued to 
grow on trend at a rate of $2 \%$ per annum. There are many possible reasons behind the fall in labour productivity. One view is that of the so-called 'supply-side pessimists' who argue that the fall in productivity is due to infrastructure, and is linked with the financial crisis (King, 2013; Bagaria et al., 2012). According to these pessimists, any attempt to stimulate the economy via monetary policy, as was attempted after the 2008 crisis through quantitative easing (QE), will lead to inflation. They argue against any relaxation of fiscal consolidation programmes and they are in favour of fiscal austerity.

Gross fixed capital formation (GFCF) is a measure of investment. In the UK as a whole, GFCF was low in the early 1990s but grew slowly until 2007; it thereafter fell sharply, and only began to rise again in 2014. Figure 2 shows that gross fixed capital formation is lowest in the UK in comparison to other advanced economies - see Table 2. Although it has declined since 1990, since the 2008 crisis the gross capital formation levels have themselves been low.

It is often assumed that labour productivity includes the amount of capital available per hour worked, the degree of technical efficiency of inputs of both labour and capital, which is called total factor productivity (TFP), and finally the intensity of the utilisation of both labour and capital within firms. The size of capital stock available to each unit of labour is an important determinant of labour productivity. After the financial crisis, increased economic uncertainty made firms more cautious about investment decisions, despite the fact that labour costs fell while capital cost initially increased (Siddiqui, 2019).

Broadbent (2013) studied the role of capital allocation across firms and sectors for productivity growth. He concluded that despite significant changes in sectoral rates of return on capital investment after the 2008 crisis, these have not been accompanied by the subsequent movement of capital stocks across sectors. This is in contrast to the expectation that in a dynamic and efficient economy, capital should respond by moving towards sectors with more profitable and higher returns.

Table 2: Investment (GFCF) Total, Annual growth rate (\%) of Major OECD Countries, $1990-2017$

\begin{tabular}{lcccccccc}
\hline Country & $\mathbf{1 9 9 5}$ & $\mathbf{2 0 0 0}$ & $\mathbf{2 0 0 5}$ & $\mathbf{2 0 1 0}$ & $\mathbf{2 0 1 2}$ & $\mathbf{2 0 1 4}$ & $\mathbf{2 0 1 6}$ & $\mathbf{2 0 1 7}$ \\
\hline Germany & -0.0 & 2.3 & 0.7 & 5.4 & -0.7 & 3.9 & 3.5 & 2.9 \\
Japan & 3.5 & 0.5 & 3.1 & -1.6 & 3.5 & 3.1 & 1.1 & 2.5 \\
UK & 4.7 & 3.4 & 5.1 & 4.1 & 2.1 & 7.2 & 2.3 & 3.5 \\
US & 5.2 & 6.4 & 6.1 & 2.2 & 6.9 & 4.9 & 1.7 & 4.0 \\
OECD Total & - & 5.0 & 5.2 & 2.3 & 2.3 & 3.5 & 2.3 & 3.8 \\
\hline
\end{tabular}

Source: https://data.oecd.org/gdp/investment-gfcf.htm. (Accessed on 17 January 2019). Note: e - estimated. 
Figure 2: Gross Fixed capital formation levels of major OECD countries (\% of GDP), 1980-2016

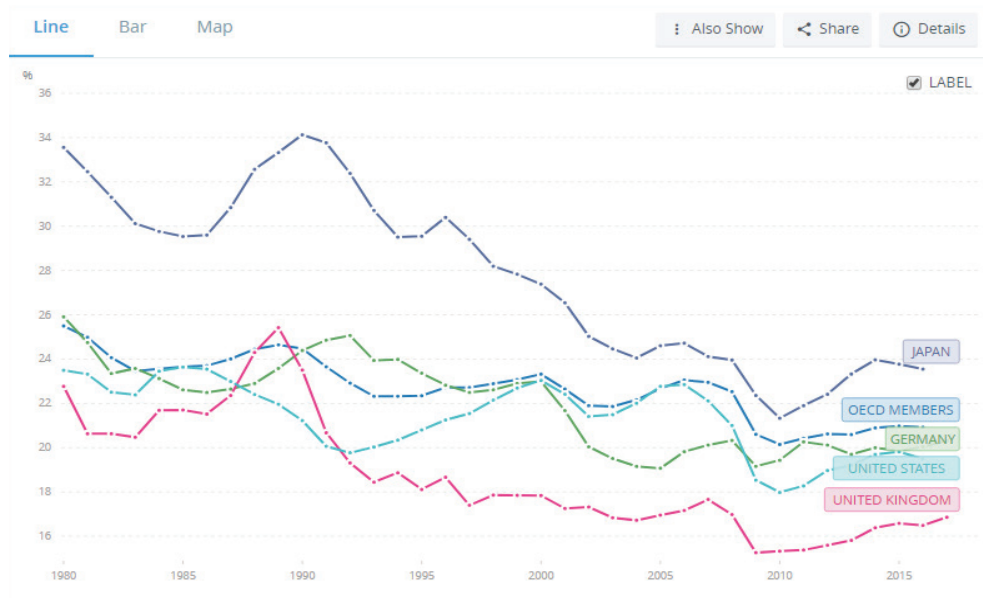

Source: https://data.worldbank.org/indicator/NE.GDI.FTOT.ZS?end=2017\&locations=OE-DE-JP-GB-US\&start=1980. (Accessed 20 August 2018). Germany is in green colour. (Accessed on 6 December 2018)

Notes: Gross fixed capital formation as defined by the European System of Accounts (ESA) consists of resident producers' acquisitions, less disposals, of fixed assets during a given period plus certain additions to the value of non-produced assets realised by the productive activity of producer or institutional units.

\section{International Productivity Trends}

In order to understand the full perspective with regards to productivity trends, we need to approach our analysis from an international, as well as a domestic perspective. We have analysed the former in an earlier section, and the latter will be discussed here. In the UK, labour productivity growth remains weak. The number of young adults enrolled in vocational education and training has risen to $43 \%$, but is still lower than other EU countries. Apprenticeships are also less popular, pursued by only $24 \%$ of A-level students compared to $59 \%$ in Switzerland and $41 \%$ in Germany in 2017. Germany's own performance over the last two decades, especially with respect to macroeconomic variables such as large trade surplus, seems to be the result of a production system and polices which include an agreement between government, businesses and trade unions to keep wages and domestic demands down. As a result of this, the country has achieved a competitive advantage in export markets.

In the UK, manufacturing accounts for a higher share of R\&D expenditure compared to other sectors. Productivity in manufacturing is also influenced by technical, social and economic and environmental changes both at the national and international levels. In the $\mathrm{UK}, \mathrm{R} \& \mathrm{D}$ is low, which is hindering innovation and its diffusion across regions, in particular in the least productive sectors. 
Haskel \& Wallis (2010) tried to answer the question of whether the productivity spillovers to the market gained any positive effect from the changes in public spending on R\&D, and whether the government should provide support for market sector investment in innovation using public funds. Haskel \& Wallis (2010) found no evidence of spillover effects from intangible investment at the market sector level, including investments in R\&D. However, they found strong evidence of market sector spillovers from public R\&D spends by research councils. They used datasets which included information about publicly funded expenditures in science, engineering and technology from 1986-87 to 2005-06. In the context of new technology, it is often argued that investment in certain types of capital could be beneficial in scope beyond those firms who make the initial investments, and these most likely could be production spillovers and network effects in relation to the public funds invested in R\&D.

The reasons cited are the following: low R\&D investment, which in 2017 was $1.7 \%$ of the GDP and well below OECD average, a relatively unskilled population and, finally, poor infrastructure. Other causes could include the fact that UK firms have, since colonial times, invested and focussed on overseas markets and capital investments rather than domestic investments, whereas Germany, Japan Sweden and South Korea have focussed on domestic markets. Also, the UK has undergone dramatic structural changes since the 1980s. These have been dominated by the rise of the financial sector, and investors have increasingly focussed on short-term profits, dividends and shares. As a result, a disproportional amount of investable funds have been transferred to finances, and indeed government policies have even encouraged such changes.

We need to analyse the reasons behind this poor productivity performance. According to Martin Wolf (2017), "International comparisons would suggest two fundamental weaknesses of the UK economy that must be addressed. First, physical investment is very low, including in research and development. Since the financial crisis, gross investment has averaged only 16.5 per cent of the gross domestic product. As the government paper, "Building our Industrial Strategy", notes, UK manufacturer is rated second worst among G7 members. Moreover, "the UK invests in total 1.7 per cent of GDP in private and public R\&D”. This is well behind the average in the OECD, let alone the leaders, which spends over 3 per cent of GDP. Second, skills remain highly deficient, particularly in the poorer regions. The overwhelming emphasis in tertiary education, in particular, has been on the expanding access to universities... an unskilled population cannot drive productivity forward... Yet so long as the UK underinvests in physical and human capital, it seems sure to remain a laggard."

As Figure 3 shows, labour productivity in the UK is low compared to other advanced economies. In 2015, GDP per hour worked was between 20 to 25\% lower than in Germany, France and the US. However, the UK's low productivity performance is not recent, it has 
merely worsened since the 2008 financial crisis. Productivity performance in the UK in the 2000 s, prior to 2008 crisis, was higher than the majority of other major economies. However, labour productivity fell sharply after the recession and, four years later, i.e., by 2012, it was still below the 2007 pre-crisis trend. It seems that crisis, leading to recession, adversely effects long-term productivity growth.

The study by Oulton and Sebastia-Barriel (2013) empirically tested a panel of 61 countries over the period between 1955 and 2010. They found the short-term growth of labour productivity was reduced by between $0.6 \%$ and $0.7 \%$ annually for each year the crisis lasted, and in the long term by between $0.84 \%$ and $1.1 \%$ (depending on the method of estimation). Their study combined advanced, emerging and developing economies. In some sectors, the measurement of output is problematic, for instance in such areas as energy and the financial services.

Labour productivity is an important concept because labour produces output and, in the context of labour theory of value, the means of production is considered to be fixed but circulating capital is not; and, whilst means of production are supposed to assist production, the output is produced by labour. Here, productivity is defined as an increase in output of use-values per unit and hence lowering the cost of output per unit is attributed to labour and not to the means of production. "[Brenner] proposed that the decline in US profitability was caused by an intensification of international competition in manufacturing, leading to systematic overcapacity and overproduction, whose resolution for capital requires more exit from manufacturing than has so far occurred" (Mohun, 2009:1025).

It was also said that, in the main, the differences between countries were due to differences in levels of both physical and human capital (O’Mahony, 1992). During the late 1980s, Germany's productivity levels were concentrated in sectors such as transportation, engineering and metals; however, the UK performed better in textiles, tobacco, food, and drinks. "The greatest improvements in relative British performance occurred in metals, nonmetallic mineral products, chemicals, vehicles and textiles. All showed substantial reduction in employment in the UK in the 1980s. The correlation between the change in relative productivity between 1968 and 1987 and change in UK employment between 1979 and 1982 ... was negative at significant at -0.6 .3 so that sectors with the greatest reduction in UK employment in the eighties appeared to experience the highest relative productivity improvement" (O’Mahony, 1992:49-50). The paper concludes, "[T]hat differences across the two countries in stocks of physical and human capital could explain much of the 1987 gap in levels of output per worker-hour between Germany and United Kingdom. Reducing this disparity in levels of capital would, therefore, appear to be important if the productivity gap is to be narrowed further". (O’Mahony, 1992:57) 
Table 3: GDP per hour worked, International Comparisons, $U K=100$ in each year.

\begin{tabular}{cccccccc}
\hline Year & France & Germany & Italy & Japan & UK & US & G7 \\
\hline 1996 & 122 & 130 & 123 & 90 & 100 & 123 & 114 \\
1997 & 123 & 129 & 123 & 89 & 100 & 123 & 113 \\
1998 & 126 & 129 & 124 & 89 & 100 & 125 & 115 \\
1999 & 126 & 132 & 122 & 90 & 100 & 127 & 116 \\
2000 & 126 & 128 & 118 & 87 & 100 & 122 & 113 \\
2001 & 127 & 129 & 116 & 87 & 100 & 123 & 113 \\
2002 & 127 & 127 & 111 & 86 & 100 & 120 & 111 \\
2003 & 123 & 128 & 110 & 86 & 100 & 122 & 111 \\
2004 & 118 & 128 & 105 & 86 & 100 & 122 & 111 \\
2005 & 123 & 127 & 106 & 88 & 100 & 126 & 114 \\
2006 & 124 & 124 & 106 & 86 & 100 & 123 & 112 \\
2007 & 126 & 126 & 109 & 88 & 100 & 124 & 113 \\
2008 & 125 & 126 & 110 & 87 & 100 & 124 & 113 \\
2009 & 129 & 129 & 113 & 88 & 100 & 129 & 116 \\
2010 & 128 & 128 & 111 & 88 & 100 & 128 & 116 \\
2011 & 129 & 132 & 112 & 88 & 100 & 128 & 116 \\
2012 & 128 & 134 & 113 & 89 & 100 & 129 & 117 \\
2013 & 132 & 135 & 113 & 90 & 100 & 128 & 117 \\
2014 & 129 & 137 & 112 & 89 & 100 & 129 & 117 \\
2015 & 129 & 136 & 112 & 90 & 100 & 129 & 117 \\
\hline
\end{tabular}

Source: http://researchbriefings.files.parliament.uk/documents/SN06492/SN06492.pdf

Figure 3: Labour Productivity in the major economies, 1989-2016. Index 2007=100*
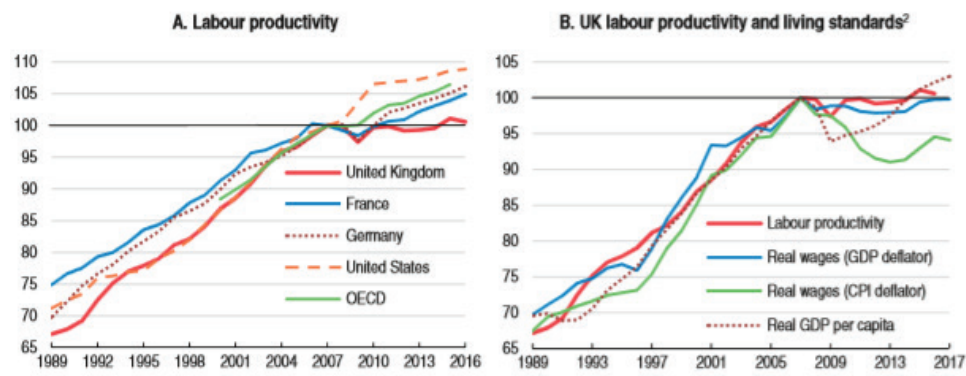

Source: OECD, 2017, October. National Account Statistics (database), pp.19. (Accessed on 10 January 2019)

Note: *. Labour productivity refers to real GDP in US dollars constant prices and constant purchasing power parities per total hours worked.

Relative levels of labour productivity were estimated to be nearly $22 \%$ higher in Germany than in British manufacturing in 1989, the gap was narrowed, but again since 2010 has widened again (see Table 3). Some scholars consider that the differences in the amount of fixed capital available to manufacturing in both countries may indicate something about the gap in labour productivity in these two countries (van Ark, 1990). Perhaps the differences in the structure of manufacturing could provide an explanation for the productivity gap 
between the UK and Germany. This will depend not only on relative sectoral growth rates, but also on capital-intense high productivity level sectors such as vehicles, engineering and chemicals (van Ark, 1990).

Global labour productivity has grown between 1990 and 2007, including in both emerging and developing markets. However, in the post-financial crisis period, there was relatively weak growth in multi-factor productivity (MFP), which reflects the efficiency with which inputs are used, i.e., through improvements in R\&D, organisational change or production management.

\section{Conclusion}

This study has found that the UK's productivity growth has been very slow relative to other major economies, which is known as the 'productivity puzzle'. As a result, the UK, which was already behind many other G7 countries, has fallen further behind. The overall level of productivity in the US economy is now $31 \%$ higher than that of the UK, while Germany's is $28 \%$ higher. It seems that a number of factors have contributed to this, such as financial institutions reducing access to bank loans for investment resulting in inefficiency in the allocation of resources within the economy. There was an absence of 'creative destruction', which could have helped productivity growth. Low public investment in R\&D in the UK, compared to other major economies, has resulted in slow innovation. This seems to be a failure in government policy in terms of taking the lead in helping and promoting a viable modern industrial sector, which could have played a positive role in increasing overall productivity growth.

Despite this, the UK has become, in some areas, highly competitive in manufacturing sectors such as aerospace and pharmaceuticals. However, productivity growth has been stagnant in other areas, and there is a clear productivity differential across sectors and regions in the UK. Therefore, government policy packaging is needed to economically strengthen lagging regions and should foster local and regional infrastructure and research and development and, as a result, enhance local economies. Generally, supportive government policies can help to foster innovation, and this can increase productivity.

This study suggests that a stronger and more viable manufacturing sector would help to build structural balance within the economy and, further, help to move it away from an overreliance on the financial sector. Reviving labour productivity growth is important in order to ensure higher living standards. Achieving this requires active state polices to raise investment in $R \& D$, innovation and skills and an active macroeconomic policy is necessary to strengthen and foster links between sectors. This will require the UK government to develop and enact a viable long-term policy of structural change within the economy. 
Peer-review: Externally peer-reviewed.

Conflict of Interest: The author has no conflict of interest to declare.

Grant Support: The author declared that this study has received no financial support.

Acknowledgements: The author would like to thank to Phil Armstrong and Huge Radice for their insightful comments and discussions which have undoubtedly strengthened the paper. And also reviewers of this journal for their comments, which definitely has improved the paper.

\section{References}

Acemoglu, D., \& Robinson, J. A. (2012). Why nations fail: The origin of power, prosperity and poverty, London: Profile Book.

Bacon, R., \& Eltis, W. (1976). Britain's economic problems: Too few producers, London: Macmillan.

Bagaria, N., Holland, D., \& Van Reenen, J. (2012). Fiscal consolidation during a depression, National Institute Economic Review, 221: 38-50, July.

Baumol, W. J. (1986). Productivity growth, convergence and welfare: What the long run data shows, American Economic Review, 76(5), 1072-85.

Broadbent, B. (2013). Conditional guidance as a response to supply uncertainty. Retrieved from www.bankofengland.co.uk/publications/Documents/speeches/2013/speech678.pdf.

Craft, N. (2012). British relative economic decline revisited: The role of competition, Explorations in Economic History, 49, 17-29.

Disney, R., Haskel, J., \& Heden, Y. (2003). Restructuring and productivity growth in UK manufacturing, Economic Journal, 113, 666-694, July.

Economist, (2018, April 14). Productivity: fix up, look sharp", pp.21, London.

Eichengreen, B. (2014). Secular stagnation: A review of the issues, Centre of Economic Policy Research, London.

Green, A., Hogarth, T., Kispeter, E., \& Owen, D. (2016). The future of productivity in manufacturing, University of Warwick. Retrieved from

https://warwick.ac.uk/fac/.../ier_2016_manufacturing_sector_productivity_report.pdf.

Haskel, J. \& Wallis, G. (2010). Public support for innovation, intangible investment and productivity growth in the UK market sector, IZA Discussion Paper No.4772, February. Retrieved from https://spiral.imperial.ac.uk/ bitstream/10044/1/5280/1/Haskel\%202010-01.pdf

Hein, E., \& Tarassow, A. (2010). Distribution, aggregate demand and productivity growth: theory and empirical results for six OECD countries based on Post-Kaleckian model, Cambridge Journal of Economics, 34:727754. DOI:10.1093/cje/bep066.

IMF (2018). United Kingdom-Selected Issues, IMF Country Report No. 18/43, February, Washington DC: IMF. Retrieved from

https://www.imf.org/ /media/Files/Publications/CR/2018/cr1843.ashx

Kaldor, N. (1975). Economic growth and Verdoorn's law: A comment on Mr. Rowthorn's article, Economic Journal, $85(340), 891-96$.

Kaldor, N. (1972). The irrelevance of equilibrium economics, Economic Journal, 82:1237-55.

Kaldor, N. (1971). The conflict in policy objectives, Economic Journal, 81, 1-18.

Katz, J. (2000). Structural change and labor productivity growth in Latin American manufacturing industries 197096, World Development, 28(9), 1583-1596. 
King, S. (2013). Putting lower unemployment ahead of higher productivity risks long-term economic damage, The Times, 19 March, London

Kitson, M., \& Michie, J. (2014). The deindustrial revolution: The rise and fall of UK manufacturing, 1870-2010, Centre for Business Research, University of Cambridge, Working paper No. 459, June.

Lall, S. (2001). Competitiveness technology and skills, Cheltenham: Edwar Elgar Publishing.

Mohun, S. (2009). Aggregate capital productivity in the US economy, 1964-2001, Cambridge Journal of Economics 33, 1023-1046. doi:10.1093/cje/ben045.

OECD Report (2015). The future of productivity, Paris: OECD. Retrieved from

https://www.oecd.org/eco/OECD-2015-The-future-of-productivity-book.pdf

O' Mahony, M. (1992). Productivity levels in British and German manufacturing industry, National Institute for Economic Review, 46-63, February, London

OECD (2017). Economic Survey - United Kingdom, October, Paris: OECD. Retrieved from

https://www.oecd.org/eco/surveys/United-Kingdom-2017-OECD-economic-survey-overview.pdf

ONS (2017). UK productivity, September. Retrieved from

https://www.ons.gov.uk/employmentandlabourmarket/peopleinwork/labourproductivity/bulletins/ labourproductivity/julytoseptember2017

Oulton, N. (2017, Fburary 7). Productivity puzzle meets delusions of adequacy, Financial Times, London.

Oulton, N., \& Sebastia-Barriel, M. (2013). Long and short-term effects of the financial crisis on labour productivity, capital and output, Working Paper No.470, London: Bank of England. ISSN 2042-2695. Retrieved from www. http://cep.lse.ac.uk/pubs/download/dp1185.pdf

Pessoa, J.P., \& Van Reenan, J. (2013). The UK productivity and job puzzle: does the answer lie in labour market flexibility, Centre for Economic Performance, LSE, Special Paper No. 31, June. Retrieved from http://cep.lse. ac.uk/pubs/download/special/cepsp31.pdf

Siddiqui, K. (2019). Government debts and fiscal deficits in the UK: A Critical Review, World Review of Political Economy, 10(1), 40-68, Pluto Journals.

Siddiqui, K. (2017). Austerity as a tool of fiscal consolidation: theoretical and empirical perspective, in (Ed.) S. Owsiak Public Finance and the New Economic Governance in the European Union, 116-66, Warsaw: Wydawnictwo Naukowe WN SA. ISBN 978-83-01-19812-1.

Siddiqui, K. (2015a). Political economy of Japan's decades long economic stagnation, Equilibrium Quarterly Journal of Economics and Economic Policy, 10(4), 9-39. Retrieved from http://dx.doi.org/10.12775/ EQUIL.2015.033.

Siddiqui, K. (2015b). Economic policy: state versus market controversy, in edited by Adam P. Balcerzak Contemporary Issues in Economy: Market or Government, 39-63, European Regional Science Association, Poland. ISBN 978-83-937843-6-3.

Siddiqui, K. (1995). Role of the state in South-East Asia, The Nation, 27 May.

Siddiqui, K., \& Dahle, T. (1989). World economy heading towards recession, Bergens Tidende, (in Norwegian) 3 July, Bergen.

Singh, A. (1977). UK industry and the World economy: a case of de-industrialisation?, Cambridge Journal of Economics, 1(2), 113-136. Retrieved from https://doi.org/10.1093/oxfordjournals.cje.a035354.

Summers, L. (2014). US economic prospects: Secular stagnation, hysteresis, and the zero lower bound, Business Economics, 49(2).

Thirlwall, A. (1983). A plain-man's guide to Kaldor's growth law, Journal of Post-Keynesian Economics, 5(3), 345-58. 
Van Ark, B. (1990). Comparative levels of manufacturing labour productivity in post-war Europe, Oxford Bulletin of Economics and Statistics, 52, 343-374, November.

Wolf, M. (2018). The long wait for productivity resurgence, Financial Times, 12 June, London. Retrieved from http://www.Wolf,Martin.FT.com

Wolf, M. (2017). The productivity challenge to British economy, Financial Times, 26 January, London. 